\title{
Development of composite biscuits made from amadumbe (Colocasia esculenta L. Schott) and soybean (Glycine $\max$ L. Merrill) and investigation of their nutritional and organoleptic properties
}

\author{
${ }^{1}$ Mokhele, T.M., ${ }^{2}$ Amonsou, E.O. and ${ }^{1, * T a b i t, ~ F . T . ~}$ \\ ${ }^{1}$ Department of Life and Consumer Sciences, University of South Africa, Cnr Christiaan de Wet Road and \\ Pioneer Avenue, Florida, Roodepoort, 1710, South Africa \\ ${ }^{2}$ Department of Biotechnology and Food Technology, Durban University of Technology, Cnr Steve Biko \\ Road and Botanic Gardens Road, Berea, Durban, 4001, South Africa
}

\section{Article history: \\ Received: 15 February 2020 \\ Received in revised form: 19 \\ March 2020 \\ Accepted: 22 March 2020 \\ Available Online: 14 April \\ 2020}

\section{Keywords:}

Amadumbe,

Biscuit,

Consumer,

Protein digestibility,

Lysine

DOI:

https://doi.org/10.26656/fr.2017.4(4).069

\begin{abstract}
The development of more popular and nutritious amadumbe based food products such as biscuits from amadumbe may be necessary to improve its utilisation and commercialization. The aim of this study was to investigate the nutritional and organoleptic properties of amadumbe-soya composite biscuits. Biscuits were prepared by combining amadumbe and soya flours at ratios 90:10, 70:30 and 50:50. There was an increase in the crude protein content of composite biscuits when the percentage of soya was increased from 10 to $30 \%$ and then $50 \%$. Similarly, an increase in the percentage of soya in composite biscuits gave rise to an increase in the levels of lysine in composite biscuits. The addition of soya to amadumbe improved the PDCAAS of composite biscuits to a value of 1 at $50 \%$ soya addition. The addition of soya flour to amadumbe flour also resulted in composite biscuits with an improved overall amino acid profile, mineral content, protein digestibility and PDCAAS (Protein Digestibility Corrected Amino Acid Score). The $50 \%$ amadumbe- $50 \%$ soya composite biscuit was identified as having the optimum quality parameters.
\end{abstract}

\section{Introduction}

Colocasia esculenta (L.) Schott, mostly known as amadumbe (South Africa), taro (Pacific Islands) and cocoyam (West Africa), is a tropical tuber crop (Figure 1) often cultivated in subsistence agriculture in many regions of Africa (McEwan et al., 2010; Kaur et al., 2013). In South Africa, the amadumbe crop is cultivated in the KwaZulu-Natal, Eastern Cape, Mpumalanga and Limpopo provinces (DAFF, 2011a). It is rich in starch (70-80\%), mucilage (10\%) with functional properties and micronutrients such as iron, zinc, vitamin $\mathrm{A}$ and vitamin B2 (DAFF, 2011a; Soudy et al., 2014; Naidoo et al., 2015). The high zinc content of amadumbe makes it a suitable food for children and adults suffering from zinc deficiency (Alcantara et al., 2013). Furthermore, amadumbe consists of very small starch granules (1.4 to $5 \mu \mathrm{m})$, which makes it highly digestible and therefore suitable for the preparation of infant foods (Jane et al., 1992).

Unlike other staple food crops such as maize and sorghum, amadumbe is still very underutilised

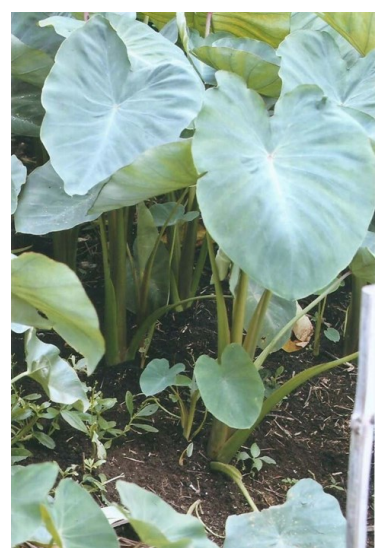

Figure 1. Amadumbe (Colocasia esculenta (L.) Schott) plants

commercially in South Africa, it is cultivated mainly in subsistence agriculture by local farmers and often sold in rural communities (DAFF, 2011b; Bvenura and Afolayan, 2015). The amadumbe crop can play an important role in alleviating food insecurity and generating income in rural communities, considering that it can survive drought conditions and requires minimal agricultural input during cultivation (Baiphethi and Jacobs, 2009; Mavengahana et al., 2013). The 
development of value-added amadumbe food products will boost its utilisation, thereby prompting large-scale cultivation by farmers, which will, in turn, boost income generation and food security in rural communities.

Amadumbe corms have limited proteins; complementing amadumbe with a protein-rich foodstuff such as soya will, therefore, improve the protein quality of amadumbe-based processed food products (Awasthi et al., 2012). Amadumbe flours have also been used as ingredients for baked products and beverages (Arenillo et al., 2012). Leguminous protein-rich grains such as soya is rich in essential amino acids such as lysine, which improves the moisture and flavour retention as well as the texture and digestibility of baked products (Farzana and Mohajan, 2015). Soya flour has been used successfully to fortify starch-based flours to produce composite biscuits with improved nutritional content, which were acceptable to consumers (Doxastakis et al., 2002; Farzana and Mohajan, 2015). The development of more popular and nutritious amadumbe based food products such as biscuits from amadumbe may be necessary to improve its utilisation and commercialisation. The purpose of this study was therefore to produce protein-rich amadumbe-soya composite biscuits as well as to investigate their nutritional and organoleptic qualities.

\section{Materials and methods}

\subsection{Preparation of amadumbe, soya and composite} flours

Amadumbe corms (Figure 2) used in the study were bought from Jozini Makhatini Research Station (KwaZulu-Natal, South Africa). Soya beans were bought from Soya Foods Company (Pty) Ltd in Bryanston, South Africa. Raw amadumbe corms were peeled using a knife and washed in running water. They were then cut into chips with a knife, washed again and dried for $16 \mathrm{~h}$ in an oven at $55^{\circ} \mathrm{C}$. The dried corms were milled into amadumbe flour using a hammer mill (Restsch $\mathrm{GmbH}$ 5657 HAAN, West German, type SK-1). The flour was passed through a $250 \mu \mathrm{m}$ sieve and then stored in large airtight zip lock bags at $4^{\circ} \mathrm{C}$ until it was used (Alcantara et al., 2013). Soya beans ( $1 \mathrm{~kg})$ were cleaned and boiled in water at $100^{\circ} \mathrm{C}$ for 30 mins to ease the removal of the seed coats. After boiling, the soya beans were dehulled manually, oven-dried for $16 \mathrm{hrs}$ at $55^{\circ} \mathrm{C}$ and milled in a hammer mill (Restsch GmbH 5657 HAAN, West German, type SK-1) to obtain flour. The soya flour was passed through a $250 \mu \mathrm{m}$ sieve and then stored in large airtight zip lock bags at $4^{\circ} \mathrm{C}$ until used (Asaam et al., 2018). Amadumbe and soya flours were mixed in the following ratios: $90: 10,70: 30$ and $50: 50$ to have amadumbe flour as the principal component using a
Kitchen Aid heavy-duty electric mixer (Model 5 KS, USA) and passed through a $250 \mu \mathrm{m}$ sieve. Composite flours were stored in airtight zip lock plastic bags and cold-stored at $4{ }^{\circ} \mathrm{C}$ until they were used (Okpala and Chinyelu, 2011).

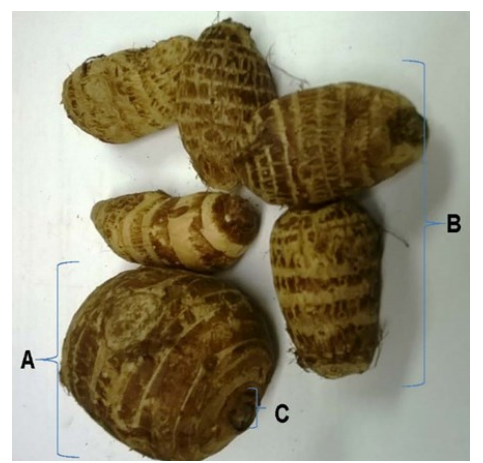

Figure 2. Amadumbe (Colocasia esculenta (L.) Schott) plants

\subsection{Preparation of amadumbe-soya composite biscuits}

The materials used for making biscuits were purchased from various supermarkets in KwaZulu-Natal, South Africa. For biscuit preparation, the basic ingredients comprised white sugar "Selati" (TSB Sugar, Malelane, South Africa), baking powder "BokomoMoirs" (Pioneer Foods Ltd, Cape Town, South Africa), sunflower oil "Sunfoil" (Willowton Oil, Pietermaritzburg, South Africa), water, vanilla essence. Various flours; amadumbe flour $(100 \%)$ or soya flour $(100 \%)$ or amadumbe-soya composite flour (90:10, 70:30 and 50:50) were used (Table 1) (Serrem et al., 2011). An electronic kitchen scale was used to measure the weight of each component. The dough was prepared by mixing all the dry ingredients, followed by the addition of oil and water. The dough was kneaded for 3 mins at medium speed using a heavy-duty electric dough mixer (Model $5 \mathrm{KS}$, USA) to obtain a firm dough. The dough was then manually rolled out on a steel tray and cut into circular shapes using a $4.5 \mathrm{~cm}$ diameter biscuit set to produce biscuit with $10 \mathrm{~mm}$ thickness. The cut dough pieces were transferred onto a baking tray lined with aluminium foil, placed in a preheated electric oven set at $180^{\circ} \mathrm{C}$ for 25 mins, and baked. After baking, biscuits were cooled down for 30 mins at ambient temperature (Serrem et al., 2011). Three batches of prepared biscuits were packed in medium-sized airtight ziplock bags and stored at $4{ }^{\circ} \mathrm{C}$ until they were analysed.

\subsection{Proximate composition analysis}

The Moisture contents, crude protein contents, crude fat contents, and ash contents of samples were analysed using the methods prescribed by the Association of Official Analytical Chemists (AOAC) procedures. The moisture was determined by drying and weighing of samples as prescribed in AOAC Method 934.01. (AOAC, 2006a). The crude protein content was 
determined using the Dumas combustion method as prescribed in AOAC Method 934.01. (AOAC, 2006b). The crude fat content was determined by the Soxhlet extraction method as prescribed in AOAC Method 990.03 (AOAC, 2006c). The dietary fibre content of samples was determined using the enzymatic gravimetric method prescribed by the AOAC Method 985.29 (AOAC, 2006d). The total carbohydrate by difference, "Total carbohydrates $=100-($ Protein + Fat + Ash + Fibre)" was determined as prescribed in AOAC (2006e). The energy value was calculated using Atwater calorie conversion factors, based on assumptions that each gram of carbohydrate, fat and protein would yield $17 \mathrm{~kJ}(4.0$ $\mathrm{kcal}), 37 \mathrm{~kJ},(9.0 \mathrm{kcal})$ and $17 \mathrm{~kJ}(4.0 \mathrm{kcal})$, respectively. The values were expressed in $\mathrm{kJ}$ (Osborne and Voogt, 1978).

\subsection{Protein quality analysis of amadumbe-soya composite biscuits}

The in vitro protein digestibility was determined as follows: The sample $(0.2 \mathrm{~g})$ was weighed and $35 \mathrm{~mL}$ of $0.1 \mathrm{M}$ phosphate buffer $(\mathrm{pH} 2)$, containing $1.5 \mathrm{mg}$ pepsin $/ \mathrm{mL}$ was added. The pepsin-sample mixture was incubated at $37^{\circ} \mathrm{C}$ for $2 \mathrm{hrs}$ with continuous shaking. Digestion was stopped by adding $2 \mathrm{~mL}$ of $2 \mathrm{M} \mathrm{NaOH}$, and the suspension was centrifuged at $4800 \mathrm{rpm}$ at $4^{\circ} \mathrm{C}$ for $20 \mathrm{mins}$ and the supernatant discarded. The residue was washed with $15 \mathrm{~mL}$ of $0.1 \mathrm{M}$ phosphate buffer: $\mathrm{pH} 7$ and centrifuged again. The supernatant was discarded, and the residue was washed on Whatman's No 3-filter paper which contained the undigested protein residue and was folded and placed in a digestion tube and dried for $2 \mathrm{hrs}$ at $80^{\circ} \mathrm{C}$. The dried sample was analysed using the micro Kjeldahl method (AOAC, 1920).

$\%$ Protein Digestibility $=\frac{\text { Total protein }- \text { Residual protein after pepsin digestion }}{\text { Total protein }} \times 100$

The amino acid composition of the protein extracts was determined using the Pico-Tag protocol as described by Bidlingmeyer et al. (1984). Sample preparation involved the hydrolysis of proteins and peptide, which was followed by the derivatisation of amino acid using the phenyl isothiocyanate (PITC) reagent. The protein in samples was hydrolysed in $6 \mathrm{M} \mathrm{HCL}$ containing $0.05 \%$ phenol at $116^{\circ} \mathrm{C}$ under vacuum for $24 \mathrm{hrs}$ (Siwela and Amonsou, 2016). The samples (1-40 $\mu \mathrm{L})$ were then injected into a liquid chromatograph system (UltiMate 3000 RSLCnano LC System) containing a Pico-Tag column and $254 \mathrm{~nm}$ fixed-wavelength detector. Two eluents, (A): $0.14 \mathrm{M}$ sodium acetate $/ 0.5 \mathrm{~mL} / 1 \mathrm{TEA}(\mathrm{pH}$ 6.35 ), and (B): $60 \%$ acetonitrile in water, were the solvent system. Amino acid scores (AAS) of samples were obtained by dividing the content of first limiting essential amino acids (histidine, threonine, lysine, tryptophan, valine, isoleucine, phenylalanine, etc.) in a test protein $(\mathrm{mg} / \mathrm{g})$ by the content of corresponding amino acid in a reference protein $(\mathrm{mg} / \mathrm{g})$ multiplied by 100 (Caire-Juvera et al., 2013). The protein digestibility corrected amino acid score (PDCAAS) was calculated by obtaining the product of the AAS and protein digestibility (Anyango et al., 2011).

\subsection{Mineral content analysis of amadumbe-soya composite biscuits}

Calcium (Ca), magnesium $(\mathrm{Mg})$, potassium $(\mathrm{K})$, sodium $(\mathrm{Na})$, Zink $(\mathrm{Zn})$, copper $(\mathrm{Cu})$, Manganese $(\mathrm{Mn})$ and iron $(\mathrm{Fe})$ were determined using an atomic absorption flame emission spectrophotometer (AA-6200 Shimadzu Corp. Kyoto Japan) with air acetylene flame at $722 \mathrm{~nm}$. Each sample was analysed in duplicate. Quantification was accomplished by comparison with a standard curve drawn using a standard solution of known concentration at $0.5,1.00,1.5$ and $2.5 \mathrm{ppm}$. Phosphorus (P) was determined by the flame photometric method (AOAC, 1990a). Each sample was analysed in duplicate.

\subsection{Consumer acceptance of amadumbe-soya bean composite biscuits}

After obtaining ethical clearance (2015/CAES/023) form the college of agriculture and life sciences ethics committee, a total of fifty individuals were screened and recruited from the Durban University of Technology campus in South Africa to constitute an untrained consumer test panel. The screening criteria included the consumption of biscuits at least once a week and the absence of food allergies. Members of the panel were told that they could withdraw from the study at any time and they were asked to sign a consent form prior to the tasting of samples. A total of 5 types of biscuits, amadumbe $(100 \%)$, soya $(100 \%)$ and amadumbe-soya composites (with ratios 90:10, 70:30 and 50:50), each with a 3-digit number code, were presented to each member of the panel. Each sample was tested for colour, aroma, taste, texture and overall acceptability using a 9point hedonic scale. The nine structural acceptability levels ranged from 9 "like extremely", 8 "like very much", 7 "liked moderately", 6 "liked slightly", 5 "neither like nor dislike", 4 "disliked slightly", 3 "disliked moderately", 2 "dislike very much" and 1 "dislike extremely". Questions and scales were displayed on sensory evaluation forms (Kayitesi et al., 2010).

\section{Results and discussion}

\subsection{Proximate composition of amadumbe-soya composite} biscuits

A significant decrease $(p \leq 0.05)$ in the moisture content only occurred when the percentage of soya in the 
Table 1. Formulation of preparation of wheat, amadumbe, soya and amadumbe-soya composite biscuits

\begin{tabular}{|c|c|c|c|c|c|c|c|}
\hline Samples & $\begin{array}{l}\text { Amadumbe } \\
\text { flour }(\mathrm{g})\end{array}$ & $\begin{array}{l}\text { Soya flour } \\
(\mathrm{g})\end{array}$ & Sugar (g) & $\begin{array}{c}\text { Sunflower } \\
\text { oil (g) }\end{array}$ & $\begin{array}{c}\text { Baking } \\
\text { powder }(\mathrm{g})\end{array}$ & $\begin{array}{c}\text { Vanilla } \\
\text { essence }(\mathrm{g})\end{array}$ & Water $(\mathrm{g})$ \\
\hline Amadumbe flour (100\%) & $225(48.7)$ & 0 & $56(12.1)$ & $66(14.3)$ & $1.5(0.3)$ & $13.5(2.9)$ & $100(21.7)$ \\
\hline Soya $(100 \%)$ & 0 & $225(48.7)$ & $56(12.1)$ & $66(14.3)$ & $1.5(0.3)$ & $13.5(2.9)$ & $100(21.7)$ \\
\hline Amadumbe (90): soya flour (10) & $202.5(43.8)$ & $22.5(4.9)$ & $56(12.1)$ & $66(14.3)$ & $1.5(0.3)$ & $13.5(2.9)$ & $100(21.7)$ \\
\hline Amadumbe (70): soya flour (30) & $157.5(34.1)$ & $67.5(14.6)$ & $56(12.1)$ & $66(14.3)$ & $1.5(0.3)$ & $13.5(2.9)$ & $100(21.7)$ \\
\hline Amadumbe (50): soya flour (50) & $112.5(24.4)$ & $112.5(24.4)$ & $56(12.1)$ & $66(14.3)$ & $1.5(0.3)$ & $13 . .5(2.9)$ & $100(21.7)$ \\
\hline
\end{tabular}

Figures in parentheses are percentages (Serrem et al., 2011).

Table 2. Proximate composition of amadumbe-soya composite biscuits ( $\mathrm{g} / 100 \mathrm{~g})$

\begin{tabular}{lccccc}
\hline \multirow{2}{*}{ Variables } & \multicolumn{5}{c}{ Flour blends (amadumbe: soya) biscuits } \\
\cline { 2 - 6 } & Amadumbe $(100 \%)$ & Soya $-100 \%$ & $\begin{array}{c}\text { Amadumbe-soya } \\
(90: 10)\end{array}$ & $\begin{array}{c}\text { Amadumbe-soya } \\
(70: 30)\end{array}$ & $\begin{array}{c}\text { Amadumbe-soya } \\
(50: 50)\end{array}$ \\
\hline Moisture & $7.44 \pm 0.08^{\mathrm{bc}}$ & $6.07 \pm 0.24^{\mathrm{d}}$ & $8.42 \pm 0.03^{\mathrm{a}}$ & $8.22 \pm 0.08^{\mathrm{a}}$ & $6.76 \pm 0.16^{\mathrm{cd}}$ \\
Ash & $3.45 \pm 0.01^{\mathrm{a}}$ & $2.62 \pm 0.23^{\mathrm{c}}$ & $3.35 \pm 0.08^{\mathrm{a}}$ & $3.13 \pm 0.05^{\mathrm{b}}$ & $3.03 \pm 0.01^{\mathrm{b}}$ \\
Fat & $19.59 \pm 0.41^{\mathrm{e}}$ & $37.3 \pm 0.17^{\mathrm{a}}$ & $21.2 \pm 0.18^{\mathrm{d}}$ & $24.78 \pm 0.05^{\mathrm{c}}$ & $28.8 \pm 0.35^{\mathrm{b}}$ \\
Dietary fibre & $8.28 \pm 0.28^{\mathrm{e}}$ & $15.75 \pm 0.74^{\mathrm{a}}$ & $10.04 \pm 0.82^{\mathrm{d}}$ & $11.13 \pm 0.39^{\mathrm{c}}$ & $13.38 \pm 0.03^{\mathrm{b}}$ \\
Crude protein & $4.59 \pm 0.00^{\mathrm{f}}$ & $32.3 \pm 0.08^{\mathrm{a}}$ & $7.0 \pm 0.04^{\mathrm{e}}$ & $13.2 \pm 0.14^{\mathrm{c}}$ & $19.2 \pm 0.18^{\mathrm{b}}$ \\
Total Carbohydrates & $64.93 \pm 0.73^{\mathrm{a}}$ & $30.65 \pm 0.26^{\mathrm{f}}$ & $59.86 \pm 0.19^{\mathrm{c}}$ & $50.72 \pm 0.16^{\mathrm{d}}$ & $42.24 \pm 0.04^{\mathrm{e}}$ \\
Energy value (Kcal) & 600.7 & 501.07 & 449.9 & 437.34 & 414.73 \\
\hline
\end{tabular}

Values expressed as Mean \pm SD and Mean within rows with the same superscript letters are not significantly different ( $\mathrm{p} \geq 0.05)$, otherwise significantly different at $(\mathrm{p} \leq 0.05)$.

composite biscuits was increased from 30 to $50 \%$ (Table 2 ). The moisture content of biscuits is described as an indicator of dry matter in the food products (Adebowale et al., 2012). The moisture content of all biscuits was above $5 \%$, higher than the recommended moisture content of 5\% and lower (Patel et al., 2019); therefore the $50 \%$ amadumbe composite biscuit was recommended for long term storage because it had the lowest moisture content. A significant reduction $(p \leq 0.05)$ in the ash content of amadumbe-soya composite biscuits occurred when the percentage of soya was increased from $10 \%$ to $30 \%$ but not significantly from $30 \%$ to $50 \%$ in the composite biscuits (Table 1). The ash content, which is inorganic residue such as mineral that remains after water and organic matter have been removed from biscuits (Omoba and Omogbemile, 2013; Perring and Tschopp, 2019), was higher in amadumbe than in soya. The 30\% amadumbe composite biscuit with the highest ash is therefore recommended in order to produce biscuits with optimum inorganic residue.

The fat content of amadumbe-soya composite biscuits increased significantly $(p \leq 0.05)$ with the increase in the percentage of soya in the composite from $10 \%$ to $30 \%$ and $50 \%$ (Table 2). Biscuits with high fat content have been found to possess lower density and are more liked by consumers (Biguzzi et al., 2015). The progressive increase in the fat content is due to soya beans being rich in oil ranging from 20-22\% (Mishra and Chandra, 2012). Despite its ability to promote rancidity, fat contributes to the texture, structural integrity, lubrication and increased air incorporation in dough in the making of biscuits (Sozer et al., 2014). There was a significant increase $(p \leq 0.05)$ in the dietary fibre contents of composite biscuits with an increase in the percentage of soya flours from $10 \%$ to $30 \%$ and then $50 \%$. (Table 2). The consumption of biscuits with high dietary fibre content can improve colorectal health (Jin et al., 2019). The 50\% amadumbe composite biscuit is recommended in order to produce composite biscuits with the highest level of dietary fibre content.

There was a significant progressive increase $(\mathrm{p} \leq$ 0.05 ) in the crude protein content of composite biscuits when the percentage of soya was increased from 10 to $30 \%$ and then $50 \%$. Crude protein is an important macronutrient for the growth and maintenance of the body (Kayitesi et al., 2012). It influences food processing by trapping the starch in flour mixtures and contributes to the formation of the internal structure of biscuits (Maache-Rezzoug et al., 1998). The increase in protein content was expected considering that soya flour, which has a high protein content, has been used to enrich sorghum composites (Omoba and Omogbemile, 2013) and wheat composite biscuits (Farzana and Mohajan, 2015). Leguminous protein-rich grain such as soya has been used in compositing low protein foods to improve their protein quality (Awasthi et al., 2012). Composite biscuits with $50 \%$ amadumbe contained the highest crude protein content, and are likely to contribute more to the recommended daily protein requirements of 1.12 $\mathrm{g} / \mathrm{kg} /$ day for babies up to 6 months to $0.74 \mathrm{~g} / \mathrm{kg} /$ day for 
Table 3. Amino acid composition of amadumbe-soya composite biscuits ( $\mathrm{mg} / \mathrm{g}$ protein)

\begin{tabular}{|c|c|c|c|c|c|c|}
\hline Amino acids & Amadumbe $(100 \%)$ & Soya $(100 \%)$ & $\begin{array}{c}\text { Amadumbe-soya } \\
(90: 10)\end{array}$ & $\begin{array}{c}\text { Amadumbe-soya } \\
(70: 30)\end{array}$ & $\begin{array}{c}\text { Amadumbe-soya } \\
(50: 50)\end{array}$ & $\begin{array}{c}{ }^{\ddagger} \text { Reference } \\
\text { pattern }\end{array}$ \\
\hline \multicolumn{7}{|l|}{ Essential } \\
\hline Histidine & $19.60 \pm 0.00^{\mathrm{d}}$ & $23.69 \pm 0.66^{\mathrm{a}}$ & $21.30 \pm 1.01^{\mathrm{b}}$ & $21.97 \pm 0.00^{\mathrm{bc}}$ & $21.36 \pm 0.14^{\mathrm{c}}$ & 16 \\
\hline Threonine & $39.22 \pm 0.00^{\mathrm{a}}$ & $36.53 \pm 0.44^{\mathrm{c}}$ & $38.01 \pm 1.01^{\mathrm{b}}$ & $36.99 \pm 0.53^{b c}$ & $37.08 \pm 0.74^{\mathrm{c}}$ & 25 \\
\hline Valine & $47.93 \pm 0.00^{\mathrm{a}}$ & $41.18 \pm 0.44^{\mathrm{c}}$ & $47.53 \pm 2.22^{\mathrm{a}}$ & $46.29 \pm 0.54^{\mathrm{ab}}$ & $44.59 \pm 2.21^{\mathrm{b}}$ & 40 \\
\hline Isoleucine & $31.59 \pm 1.54^{\mathrm{c}}$ & $40.25 \pm 0.44^{\mathrm{a}}$ & $35.59 \pm 1.01^{\mathrm{b}}$ & $35.75 \pm 0.00^{\mathrm{b}}$ & $35.98 \pm 1.47^{\mathrm{b}}$ & 31 \\
\hline Leucine & $78.43 \pm 0.00^{\mathrm{a}}$ & $71.06 \pm 0.66^{\mathrm{c}}$ & $77.69 \pm 1.01^{\mathrm{a}}$ & $75.21 \pm 0.00^{\mathrm{ab}}$ & $74.97 \pm 1.84^{\mathrm{b}}$ & 61 \\
\hline Phenylalanine & $53.38 \pm 1.54^{\mathrm{a}}$ & $47.06 \pm 1.32^{\mathrm{c}}$ & $52.75 \pm 1.00^{\mathrm{a}}$ & $51.59 \pm 0.54^{\mathrm{ab}}$ & $49.01 \pm 1.10^{\mathrm{b}}$ & 41 \\
\hline Lysine & $30.50 \pm 0.00^{\mathrm{c}}$ & $52.01 \pm 2.63^{\mathrm{a}}$ & $32.65 \pm 0.00^{\mathrm{c}}$ & $45.08 \pm 0.53^{\mathrm{b}}$ & $49.88 \pm 1.48^{\mathrm{a}}$ & 48 \\
\hline \multicolumn{7}{|l|}{ Non-essential } \\
\hline Aspartic acid & $127.45 \pm 1.54^{\mathrm{a}}$ & $96.59 \pm 10.94^{\mathrm{d}}$ & $126.35 \pm 1.00^{\mathrm{a}}$ & $117.58 \pm 0.00^{\mathrm{b}}$ & $112.79 \pm 3.32^{\mathrm{c}}$ & \\
\hline Glutamic acid & $106.75 \pm 0.00^{\mathrm{c}}$ & $157.44 \pm 11.1^{\mathrm{a}}$ & $100.64 \pm 2.02^{\mathrm{d}}$ & $107.07 \pm 0.00^{\mathrm{c}}$ & $127.66 \pm 5.52^{\mathrm{b}}$ & \\
\hline Serine & $54.47 \pm 0.00^{\mathrm{a}}$ & $48.61 \pm 0.88^{c}$ & $53.89 \pm 0.00^{\mathrm{a}}$ & $52.86 \pm 0.54^{\mathrm{ab}}$ & $51.96 \pm 0.74^{\mathrm{b}}$ & \\
\hline Glycine & $49.02 \pm 1.54^{\mathrm{a}}$ & $38.55 \pm 1.10^{\mathrm{d}}$ & $48.57 \pm 2.02^{\mathrm{a}}$ & $45.04 \pm 1.07^{\mathrm{b}}$ & $43.72 \pm 1.10^{\mathrm{c}}$ & \\
\hline Arginine & $59.91 \pm 1.54^{\mathrm{c}}$ & $66.10 \pm 0.66^{\mathrm{a}}$ & $60.09 \pm 3.03^{c}$ & $61.50 \pm 0.54^{\mathrm{b}}$ & $63.50 \pm 5.90^{\mathrm{ab}}$ & \\
\hline Alanine & $42.48 \pm 1.54^{\mathrm{a}}$ & $38.24 \pm 1.10^{\mathrm{c}}$ & $42.38 \pm 0.00^{\mathrm{a}}$ & $41.39 \pm 0.00^{\mathrm{ab}}$ & $40.24 \pm 1.10^{\mathrm{b}}$ & \\
\hline Proline & $41.39 \pm 0.00^{\mathrm{b}}$ & $46.60 \pm 1.10^{\mathrm{b}}$ & $45.50 \pm 1.01^{\mathrm{a}}$ & $43.18 \pm 0.00^{\mathrm{b}}$ & $42.45 \pm 1.10^{\mathrm{b}}$ & \\
\hline Tyrosine & $38.13 \pm 1.51^{\mathrm{a}}$ & $30.50 \pm 1.10^{\mathrm{d}}$ & $39.86 \pm 3.03^{\mathrm{a}}$ & $37.07 \pm 2.14^{\mathrm{b}}$ & $34.39 \pm 2.58^{\mathrm{c}}$ & \\
\hline
\end{tabular}

Values expressed as Mean \pm SD and Mean within rows with the same superscript letters are not significantly different ( $\mathrm{p} \geq 0.05)$, otherwise significantly different at $(\mathrm{p} \leq 0.05)$. ${ }^{\sharp}$ Reference pattern: amino acid scoring pattern of preschool-age child 3-10 years (WHO/FAO/UNU, 2007).

children up to 10 years for children (Garlick, 2006; De Oliveira Silva et al., 2018).

There was also a significant reduction $(p \leq 0.05)$ in the carbohydrate content and energy value of amadumbe -soya composite biscuits when the percentage of soya was increased from $10 \%$ to $30 \%$ and then $50 \%$ (Table 2). Amadumbe corms are a good source of carbohydrates and energy (Kaushal et al., 2015). Amadumbe is noted to be good for diabetics and people with gastrointestinal disorders because it contains resistant starch, which ameliorate diabetic conditions and possesses putative cholesterol-lowering effect (Simsek and El, 2012; Himeda et al., 2014). The significant reduction of carbohydrates and energy was expected because of the progressive replacement of amadumbe with increasing soya percentages in the composite biscuit formulation. The carbohydrate content of flour influences food processing by acting as a good source of metabolizable energy and by assisting in the metabolism of fats (Kaushal et al., 2012).

\subsection{The amino acid quality of amadumbe-soya composite biscuits}

The major amino acids in composite biscuits are aspartic acid and glutamic acid (Table 3) due to their significant presence $(\mathrm{p} \leq 0.05)$ in amadumbe (Mbofung et al., 2006; Njintang et al., 2014). Aspartic acid and glutamic acid, which are important components of human tissues, such as blood proteins, hormones and enzymes, contribute to the proper functioning of many biological activities in the human body (Unger and
Holzgrabe, 2018). Similarly, an increase in the percentage of soya in composite biscuits gave rise to a significant increase $(\mathrm{p} \leq 0.05)$ in the levels of lysine in composite biscuits (Table 3) due to its significant presence in soya. Amadumbe contains a relatively lower amount of lysine; the addition of soya to amadumbe, therefore, increases the levels of lysine in composite biscuits (Julianti et al., 2017). Soya beans, which are known to be a rich source of protein, have been used to complement the lysine content of lysine-limited cereal diets (Khetarpaul and Goyal, 2007).

Overall, the addition of soya flour to amadumbe flour resulted in composite biscuits with an improved amino acid profile (Table 3) and chemical score (Table 4) compared to wheat biscuits (Youssef, 2015), especially for those amino acids whose content was low in either amadumbe flour or soya flour. The amino acid score of all the composites was above the recommended reference amino acid $(\mathrm{mg} / \mathrm{g})$ (Table 3$)$ prescribed by the WHO/FAO/UNU (2007) report for a foodstuff. Amadumbe corms have been found to contain substantial amounts of leucine, threonine, arginine, valine and phenylalanine, but have low amounts of histidine, lysine and isoleucine (Adane et al., 2013; Melese and Negussie, 2015). Soya was successfully used to increase the content of those essential amino acids which were low in amadumbe. The presence of adequate quantities of all amino acids in the diet enables optimal growth and proper functioning of the body (Kayitesi et al., 2012; Caire-Juvera et al., 2013). The fortification of amadumbe flour with soya has been found to maintain adequate 
Table 4. Amino acid (chemical) scores of amadumbe-soya composite biscuit

\begin{tabular}{|c|c|c|c|c|c|}
\hline Essential amino acids & $\begin{array}{l}\text { Amadumbe } \\
(100 \%)\end{array}$ & Soya $(100 \%)$ & $\begin{array}{c}\text { Amadumbe-soya } \\
(90: 10)\end{array}$ & $\begin{array}{c}\text { Amadumbe-soya } \\
(70: 30)\end{array}$ & $\begin{array}{l}\text { Amadumbe-soya } \\
(50: 50)\end{array}$ \\
\hline Histidine & $1.23 \pm 0.01^{\mathrm{e}}$ & $1.47 \pm 0.01^{\mathrm{e}}$ & $1.34 \pm 0.01^{\mathrm{d}}$ & $1.37 \pm 0.01^{\mathrm{c}}$ & $1.40 \pm 0.01^{\mathrm{b}}$ \\
\hline Threonine & $1.57 \pm 0.01^{\mathrm{a}}$ & $1.46 \pm 0.01^{\mathrm{d}}$ & $1.52 \pm 0.01^{\mathrm{b}}$ & $1.48 \pm 0.01^{\mathrm{c}}$ & $1.48 \pm 0.01^{\mathrm{c}}$ \\
\hline Valine & $1.20 \pm 0.01^{\mathrm{a}}$ & $1.03 \pm 0.01^{\mathrm{d}}$ & $1.19 \pm 0.01^{\mathrm{a}}$ & $1.16 \pm 0.01^{\mathrm{b}}$ & $1.11 \pm 0.01^{\mathrm{c}}$ \\
\hline Isoleucine & $1.02 \pm 0.01^{\mathrm{d}}$ & $1.30 \pm 0.01^{\mathrm{a}}$ & $1.05 \pm 0.01^{\mathrm{c}}$ & $1.15 \pm 0.01^{\mathrm{b}}$ & $1.16 \pm 0.01^{\mathrm{b}}$ \\
\hline Leucine & $1.29 \pm 0.01^{\mathrm{a}}$ & $1.16 \pm 0.01^{\mathrm{d}}$ & $1.27 \pm 0.01^{\mathrm{b}}$ & $1.23 \pm 0.01^{\mathrm{c}}$ & $1.23 \pm 0.01^{\mathrm{c}}$ \\
\hline Phenylalanine & $1.30 \pm 0.01^{\mathrm{a}}$ & $1.15 \pm 0.01^{\mathrm{d}}$ & $1.29 \pm 0.01^{\mathrm{a}}$ & $1.26 \pm 0.01^{\mathrm{b}}$ & $1.20 \pm 0.01^{\mathrm{c}}$ \\
\hline Lysine & $0.64 \pm 0.01^{\mathrm{e}}$ & $1.08 \pm 0.01^{\mathrm{a}}$ & $0.68 \pm 0.01^{\mathrm{d}}$ & $0.94 \pm 0.01^{\mathrm{c}}$ & $1.04 \pm 0.01^{\mathrm{b}}$ \\
\hline
\end{tabular}

Values expressed as Mean \pm SD and Mean within rows with the same superscript letters are not significantly different ( $p \geq 0.05)$, otherwise significantly different at $(\mathrm{p} \leq 0.05)$.

Table 5. Protein digestibility and protein digestibility corrected amino acid score (PDCAAS) amadumbe-soya biscuits

\begin{tabular}{lccc}
\hline Flours & Protein digestibility (\%) & Limiting amino acid chemical score & PDCAAS \\
\hline Amadumbe (100\%) & 96 & Lysine (0.64) & 0.61 \\
Soya (100\%) & 99 & Valine (1.03) & 1.02 \\
Amadumbe-soya (90:10) & 97 & Lysine (0.68) & 0.66 \\
Amadumbe-soya (70:30) & 98 & Lysine (0.94) & 0.92 \\
Amadumbe-soya (50:50) & 99 & Lysine (1.04) & 1.03 \\
\hline
\end{tabular}

levels of heat-sensitive amino acids such as lysine, biscuits. The lower protein digestibility of $100 \%$ arginine and histidine (Obadina et al., 2016). The amadumbe biscuits could be due to the presence of antiaddition of soya resulted in composite biscuits with improved protein quality which, in turn, enhances their ability to support optimal growth in humans (De Oliveira Silva et al., 2018).

Regarding protein digestibility and PDCAAS, lysine was found to be the limiting amino acid for amadumbe biscuits and amadumbe-soya composite biscuits, while valine was the limiting amino acid for the soya biscuits. The increase in the percentage of soya resulted in a small increase in the in vitro protein digestibility of composite biscuits up to a value of 0.99 at $50 \%$ soya bean addition (Table 5). Protein digestibility, which is an estimate of the amount of protein that can be absorbed into the body from a protein diet (Okpala and Chinyelu, 2011), was higher in $100 \%$ soya biscuits than in $100 \%$ amadumbe nutritional factors such as phytic acids, which could have connected with protein to form a protein-mineral complex that can inhibit the activities of the proteindegrading enzyme (Rathi et al., 2004; Soudy et al., 2014). The $50 \%$ amadumbe and $50 \%$ soya composite flour had the highest digestibility values and are therefore recommended to produce amadumbe composite biscuits with the most protein digestibility.

The addition of soya to amadumbe improved the PDCAAS of composite biscuits to a value of 1 at $50 \%$ soya addition (Table 5). The PDCAAS measures the quality of protein in terms of its available indispensable amino acid content and its digestibility (Dabbour and Takruri, 2002; Vilakati et al., 2015). The PDCAAS increased slightly with an increase in the percentage of

Table 6. Mineral composition of amadumbe-soya composite biscuits

\begin{tabular}{|c|c|c|c|c|c|}
\hline Mineral & Amadumbe $(100 \%)$ & Soya $(100 \%)$ & $\begin{array}{c}\text { Amadumbe-soya } \\
(90: 10)\end{array}$ & $\begin{array}{c}\text { Amadumbe-soya } \\
(70: 30)\end{array}$ & $\begin{array}{c}\text { Amadumbe-soya } \\
(50: 50)\end{array}$ \\
\hline $\mathrm{Ca}(\mathrm{g} / 100 \mathrm{~g})$ & $0.08 \pm 0.00^{\mathrm{d}}$ & $0.15 \pm 0.00^{\mathrm{a}}$ & $0.09 \pm 0.00^{\mathrm{c}}$ & $0.10 \pm 0.00^{\mathrm{a}}$ & $0.11 \pm 0.01^{\mathrm{a}}$ \\
\hline $\operatorname{Mg}(g / 100 \mathrm{~g})$ & $0.05 \pm 0.00^{\mathrm{e}}$ & $0.13 \pm 0.01^{\mathrm{a}}$ & $0.06 \pm 0.00^{\mathrm{d}}$ & $0.08 \pm 0.00^{\mathrm{c}}$ & $0.09 \pm 0.01^{\mathrm{b}}$ \\
\hline $\mathrm{K}(\mathrm{g} / 100 \mathrm{~g})$ & $1.20 \pm 0.03^{\mathrm{a}}$ & $0.54 \pm 0.01^{\mathrm{d}}$ & $1.13 \pm 0.01^{\mathrm{a}}$ & $0.99 \pm 0.13^{b}$ & $0.79 \pm 0.13^{\mathrm{c}}$ \\
\hline $\mathrm{Na}(\mathrm{g} / 100 \mathrm{~g})$ & $0.14 \pm 0.01^{\mathrm{a}}$ & $0.09 \pm 0.01^{\mathrm{d}}$ & $0.12 \pm 0.00^{\mathrm{b}}$ & $0.11 \pm 0.01^{\mathrm{bc}}$ & $0.11 \pm 0.00^{\mathrm{bc}}$ \\
\hline $\mathrm{K} / \mathrm{Ca}^{+} \mathrm{Mg}(\mathrm{g} / 100 \mathrm{~g})$ & $3.74 \pm 0.11^{\mathrm{a}}$ & $0.78 \pm 0.01^{\mathrm{f}}$ & $3.07 \pm 0.03^{\mathrm{b}}$ & $2.19 \pm 0.04^{\mathrm{c}}$ & $1.60 \pm 0.16^{\mathrm{d}}$ \\
\hline$P(g / 100 g)$ & $0.17 \pm 0.00^{\mathrm{e}}$ & $0.44 \pm 0.00^{\mathrm{a}}$ & $0.19 \pm 0.00^{\mathrm{d}}$ & $0.25 \pm 0.01^{\mathrm{c}}$ & $0.30 \pm 0.01^{\mathrm{b}}$ \\
\hline $\mathrm{Zn}(\mathrm{mg} / \mathrm{kg})$ & $4.00 \pm 0.00^{\mathrm{f}}$ & $30.0 \pm 0.00^{\mathrm{a}}$ & $9.00 \pm 0.00^{\mathrm{e}}$ & $13.0 \pm 0.00^{\mathrm{d}}$ & $17.00 \pm 0.00^{\mathrm{c}}$ \\
\hline $\mathrm{Cu}(\mathrm{mg} / \mathrm{kg})$ & $1.00 \pm 1.41^{\mathrm{c}}$ & $6.50 \pm 0.71^{\mathrm{a}}$ & $0.75 \pm 0.36^{\mathrm{c}}$ & $2.00 \pm 0.00^{\mathrm{bc}}$ & $4.00 \pm 1.41^{\mathrm{b}}$ \\
\hline $\mathrm{Mn}(\mathrm{mg} / \mathrm{kg})$ & $2.00 \pm 0.00^{\mathrm{e}}$ & $23.0 \pm 0.00^{\mathrm{a}}$ & $4.75 \pm 1.06^{\mathrm{d}}$ & $11.0 \pm 0.00^{\mathrm{c}}$ & $14.00 \pm 1.41^{\mathrm{b}}$ \\
\hline $\mathrm{Fe}(\mathrm{mg} / \mathrm{kg})$ & $24.0 \pm 2.83^{\mathrm{c}}$ & $38.0 \pm 0.00^{\mathrm{b}}$ & $26.0 \pm 0.00^{\mathrm{c}}$ & $32.0 \pm 1.41^{\mathrm{b}}$ & $38.00 \pm 2.83^{b c}$ \\
\hline
\end{tabular}

Values expressed as Mean \pm SD and Mean within rows with the same superscript letters are not significantly different ( $\mathrm{p} \geq 0.05)$, otherwise significantly different at $(\mathrm{p} \leq 0.05)$. 
Table 7. Consumer acceptability of amadumbe-soya composite biscuits $(\mathrm{N}=50)$

\begin{tabular}{|c|c|c|c|c|c|}
\hline Biscuits & Colour & Aroma & Taste & Texture & Overall acceptability \\
\hline Amadumbe (100\%) & $6.96 \pm 1.80^{\mathrm{ab}}$ & $6.86 \pm 1.77^{\mathrm{a}}$ & $6.52 \pm 1.98^{\mathrm{ab}}$ & $6.02 \pm 2.08^{\mathrm{a}}$ & $6.24 \pm 1.95^{\mathrm{a}}$ \\
\hline Soya $(100 \%)$ & $7.60 \pm 1.83^{\mathrm{a}}$ & $6.48 \pm 1.99^{\mathrm{a}}$ & $6.36 \pm 1.87^{\mathrm{a}}$ & $6.74 \pm 1.97^{b}$ & $6.28 \pm 2.19^{\mathrm{a}}$ \\
\hline Amadumbe-soya (90:10) & $6.90 \pm 1.72^{\mathrm{ab}}$ & $6.70 \pm 1.79^{\mathrm{a}}$ & $6.44 \pm 2.03^{\mathrm{b}}$ & $6.00 \pm 2.07^{\mathrm{a}}$ & $6.52 \pm 1.92^{\mathrm{a}}$ \\
\hline Amadumbe soya (70:30) & $6.70 \pm 2.14^{b}$ & $6.72 \pm 1.77^{\mathrm{a}}$ & $6.62 \pm 1.82^{\mathrm{ab}}$ & $6.32 \pm 1.85^{\mathrm{a}}$ & $6.50 \pm 2.00^{\mathrm{ab}}$ \\
\hline Amadumbe-soya (50:50) & $7.26 \pm 1.68^{\mathrm{ab}}$ & $6.96 \pm 1.71^{\mathrm{a}}$ & $7.20 \pm 1.43^{\mathrm{b}}$ & $6.70 \pm 1.88^{\mathrm{ab}}$ & $6.88 \pm 1.86^{\mathrm{b}}$ \\
\hline
\end{tabular}

Values expressed as Mean \pm SD and Mean within rows with the same superscript letters are not significantly different ( $\mathrm{p} \geq 0.05)$, otherwise significantly different at $(\mathrm{p} \leq 0.05)$. Hedonic scale: 9 "like extremely", 8 "very much", 7 "like moderately", 6 "like slightly", 5 "neither like nor dislike", 4 "dislike slightly", 3 “dislike moderately", 2 "dislike very much" and 1 "dislike extremely".

soya in composite biscuits, thereby ensuring that adequate amounts of the essential amino acid, such as lysine, are present in amadumbe composite biscuits (Shaheen et al., 2016). Soya has been used elsewhere to improve protein digestibility and PDCAAS sorghum biscuits (Serrem et al., 2011). The 50\% amadumbe composite is recommended to produce biscuits with PDCAAS close to 1 .

\subsection{Mineral analysis of amadumbe-soya composite biscuits}

There was an increase in the content of $\mathrm{Ca}, \mathrm{Mg}, \mathrm{P}$, $\mathrm{Zn}, \mathrm{Cu}, \mathrm{Mn}$ and $\mathrm{Fe}$ in composite biscuits when the percentage of soya in the composite biscuits was increased. The increase in the mineral content was only significant $(\mathrm{p} \leq 0.05)$ for $\mathrm{Mg} \mathrm{P}, \mathrm{Zn}, \mathrm{Mn}$ and $\mathrm{K}$. However, there was a decrease in the content of $\mathrm{K}$ and $\mathrm{Na}$ in composite biscuits when the percentage of soya was increased (Table 6). There was an increase in the amounts of $\mathrm{Fe}, \mathrm{Zn}$ and $\mathrm{Mn} \mathrm{Fe}$ in $100 \%$ soya biscuits, which was expected since soya beans have been found to contain a substantial amount of these minerals (Gharibzahedi and Jafari, 2017). Amadumbe corms have also been found to contain substantial amounts of $\mathrm{K}$ and Fe (Mergedus et al., 2015; Arici et al., 2016). Most minerals, especially $\mathrm{Na}$ and $\mathrm{K}$, are important in maintaining the osmotic balance of the fluids in the body (Mergedus et al., 2015), as well as controlling the absorption of glucose and many other compounds in the body (Omoba and Omogbemile, 2013). As reflected in the total ash values, the addition of soya flour to amadumbe flour resulted in composite biscuits with improved amounts of individual minerals, especially those that were lacking in either amadumbe flour or soya flour. None of the composite biscuits possessed an outright higher amount of mineral.

\subsection{Consumer acceptance of amadumbe-soya composite biscuits}

An increase in the percentage of soya in the amadumbe composite biscuits did not produce any significant difference $(p \geq 0.05)$ in the acceptability of the colour, aroma, taste, texture and overall acceptability of composite biscuits (Table 7). Hence, all the composite biscuits possessed desirable sensory properties (Yadav et al., 2012) and any of them could be used to produce amadumbe composite biscuits.

\section{Conclusion}

An increase in the percentage of soya in the formulation produced biscuits with a significant decrease in moisture, ash content, carbohydrate content and energy of amadumbe-soya composite biscuits. Conversely, an increase in the percentage of soya in the formulation produced composite biscuits with an increase in crude protein and lysine content of amadumbe-soya composite biscuits. The addition of soya flour to amadumbe flour resulted in composite biscuits with an overall improved amino acid profile, especially in those amino acids whose content was low in either amadumbe flour or soya flour. The addition of soya to amadumbe improved the protein digestibility and the PDCAAS of the composite biscuits. The addition of soya flour to amadumbe flour resulted in composite biscuits with improved amounts of individual minerals, especially those that were low in either amadumbe flour or soya flour. There was no significant difference in consumer response to the colour, aroma, taste, texture and overall acceptability of the different formulations of composite biscuits. The $50 \%$ amadumbe- $50 \%$ soya composite biscuit was identified as having the optimum quality parameters. We recommend the usage of the $50 \%$ amadumbe- $50 \%$ soya formulation to produce amadumbe biscuits with optimal nutritional and organoleptic properties.

\section{Conflict of Interest}

The authors declare no conflict of interest.

\section{Acknowledgments}

We acknowledge the Department of Research at the University of South Africa for providing the funds required for this study. 


\section{References}

Adane, T., Shimelis, A., Negussie, R., Tilahum, B. and Haki, G.D. (2013). Effect of processing method on the proximate composition, mineral content and antinutritional factors of taro (Colocasia esculenta) grown in Ethiopia. African Journal of Food, Agriculture, Nutrition and Development, 13, 73857398.

Adebowale, A.A., Adegoke, M.T., Sanni, S.A., Adegunwa, M.O. and Fetuga, G.O. (2012). Functional properties and biscuit making potentials of sorghum-wheat flour composite. American Journal of Food Technology, 7(6), 372-379. https:// doi.org/10.3923/ajft.2012.372.379

Alcantara, R.M., Hurtada, W.A. and Dizon, E.I. (2013). The nutritional value and phytochemical components of taro [Colocasia esculenta (L.) Schott] powder and its selected processed foods. Journal of Nutrition and Food Sciences, 3(3), 1-7. https:// doi.org/10.4172/2155-9600.1000207

Anyango, J.O., De Kock, H.L. and Taylor, R.N. (2011). Impact of cowpea addition on the Protein Digestibility Corrected Amino Acid Score and other protein quality parameters of traditional African foods made from non-tannin and tannin sorghum. Food Chemistry, 124(3), 775-780. https:// doi.org/10.1016/j.foodchem.2010.06.094

AOAC. (1920). Official methods of analysis Crude Protein (Total) in flour. Method 920.87. Gaithersburg, USA: AOAC.

AOAC. (2006a). Official methods of analysis: Proximate Analysis and Calculations - Moisture (M). Item 105. Association of Analytical Communities. Gaithersburg, USA: AOAC.

AOAC. (2006b). Official methods of analysis: Proximate Analysis and Calculations - Total Nitrogen or Crude Protein (CP). Item 76. Association of Analytical Communities. $17^{\text {th }}$ ed. Gaithersburg, USA: AOAC.

AOAC. (2006c). Official methods of analysis: Proximate Analysis and Calculations - Crude Fat (CF). Item 17. Association of Analytical Communities. $17^{\text {th }}$ ed. Gaithersburg, USA: AOAC.

AOAC. (2006d). Official methods of analysis: Proximate Analysis and Calculations - Total Dietary Fiber (TDF) in Foods. Item 7. Association of Analytical Communities. $17^{\text {th }}$ ed. Gaithersburg, USA: AOAC.

AOAC. (2006e). Official methods of analysis: Total Carbohydrates, crude 'by difference' Calculation: 100 percent minus percent $(\mathrm{CP}+\mathrm{Ash}+$ Crude Fat + M). Association of Analytical Communities. $17^{\text {th }} \mathrm{ed}$. Gaithersburg, USA: AOAC.

Arenillo, S.A., Montero, R.B. and Magsino, R.F. (2012).
Performance of taro flour on diversified baked products using two processing methods. International Peer Reviewed Journal, 2, 130-148.

Arici, M., Yildirim, R.M., Özülkü, G., Yaşar, B. and Toker, O.S. (2016). Physicochemical and nutritional properties of taro (Colocasia esculenta L. Schott) flour as affected by drying temperature and air velocity. $L W T, 74,434-440$. https://doi.org/10.1016/ j.lwt.2016.08.006

Asaam, E.S., Adubofuor, J., Amoah, I. and Apeku, O.J.D. (2018). Functional and pasting properties of yellow maize-soya bean-pumpkin composite flours and acceptability study on their breakfast cereals. Cogent Food and Agriculture, 4, 1501932. https:// doi.org/10.1080/23311932.2018.1501932

Awasthi, I., Siraj, P., Tripathi, M. and Tripathi, V. (2012). Development of soy fortified high protein and high calorie supplementary biscuits. Indian Journal of Scientific Research, 3(1), 51-58.

Baiphethi, M.N. and Jacobs, S.P.T. (2009). The contribution of subsistence farming to food security in South Africa. Agrekon, 48(4), 459-482. https:// doi.org/10.1080/03031853.2009.9523836

Bidlingmeyer, B.A., Cohen, S.A. and Tarvin, T.L. (1984). Rapid analysis of amino acids using precolumn derivatization. Journal of Chromatography $B$, 336(1), 93-104. https://doi.org/10.1016/S03784347(00)85133-6

Biguzzi, C., Lange, C. and Schlich, P. (2015). Effect of sensory exposure on liking for fat- or sugar-reduced biscuits. Appetite, 95, 317-323. https:// doi.org/10.1016/j.appet.2015.07.001

Bvenura, C. and Afolayan, A.J. (2015). The role of wild vegetables in household food security in South Africa: A review. Food Research International, 76 (4), 1001-1011.

Caire-Juvera, G., Francisco, A., Vazquez-Ortiz, F.A. and Grijalva-Haro, M.I. (2013). Amino acid composition, score and in vitro protein digestibility of foods commonly consumed in Northwest Mexico. Nutrición Hospitalaria, 28(2), 365-371.

Dabbour, I.R. and Takruri, H.R. (2002). Protein digestibility using corrected amino acid score method (PDCAAS) of four types of mushrooms grown in Jordan. Plant Foods for Human Nutrition, 57, 13-24. https://doi.org/10.1023/ A:1013110707567

DAFF. (2011a). Most common indigenous food crops of South Africa. Directorate: Plant Production. Department of Agriculture, Forestry and Fisheries (DAFF), South Africa. Retrieved on August 19, 2019 from DAFF Website: https://www.nda.agric.za/ 
docs/Brochures/Indigfoodcrps.pdf

DAFF. (2011b). Production guidelines for amadumbe.

Directorate: Plant Production, Department of Agriculture, Forestry and Fisheries (DAFF), South Africa. Retrieved on August 19, 2019 from DAFF Website: https://www.daff.gov.za/Daffweb3/ Portals/0/Brochures\%20and\%20Production\% 20guidelines/Production\%20Guidelines\% 20Amadumbe.pdf

De Oliveira Silva, F., Miranda, T.G., Justo, T., Silva Frasão, B., Conte-Junior, C.A., Monteiro, M. and Perrone, D. (2018). Soybean meal and fermented soybean meal as functional ingredients for the production of low-carb, high-protein, high-fiber and high isoflavones biscuits. $L W T, 90,224-231$. https:// doi.org/10.1016/j.lwt.2017.12.035

Doxastakis, G., Zafiriadis, I., Irakli, M., Marlani, H. and Tananaki, C. (2002). Lupin, soya and triticale addition to wheat flour doughs and their effect on rheological properties. Food Chemistry, 77(2), 219227. https://doi.org/10.1016/S0308-8146(01)00362-4

Farzana, T. and Mohajan, S. (2015). Effect of incorporation of soy flour to wheat flour on nutritional and sensory quality of biscuits fortified with mushroom. Food Science and Nutrition, 3(5), 363-369. https://doi.org/10.1002/fsn3.228

Garlick, P.J (2006). Protein requirements of infants and children. In Rigo, J. and Ziegler, E.E. (Eds). $58^{\text {th }}$ Nestlé nutrition workshop, pediatric program, p. 3950. Basel: Nestex Ltd. https:// doi.org/10.1159/000095009

Gharibzahedi, S.M.T. and Jafari, S.M. (2017). The importance of minerals in human nutrition: Bioavailability, food fortification, processing effects and nanoencapsulation. Trends in Food Science and Technology, 62, 119-132. https://doi.org/10.1016/ j.tifs.2017.02.017

Himeda, M., Yanou, N.N., Fombang, E., Facho, B., Kitissou, P., Mbofung, C.M.F. and Scher, J. (2014). Chemical composition, functional and sensory characteristics of wheat-taro composite flours and biscuits. Journal of Food Science and Technology, 51(9), 1893-1901. https://doi.org/10.1007/s13197012-0723-y

Jane, J., Shen, L., Chen, J., Lim, S., Kasemsuwan, T. and Nip, W.K. (1992). Physical and chemical studies of taro starches and flours. Cereal Chemistry, 69(5), 528-535.

Jin, Y., Yang, T. and Ding, W. (2019). Effect of dietary cholesterol intake on the risk of esophageal cancer: a meta-analysis. The Journal of International Medical Research, 47(9), 4059-4068. https:// doi.org/10.1177/0300060519865632

Julianti, E, Rusmarilin, H., Ridwansyah, and Yusraini, E. (2017). Functional and rheological properties of composite flour from sweet potato, maize, soybean and xanthan gum. Journal of Saudi Society of Agricultural Sciences, 16(2), 171-177. https:// doi.org/10.1016/j.jssas.2015.05.005

Kaur, M., Kaushal, P. and Sandhu, K.S. (2013). Studies on physicochemical and pasting properties of taro (Colocasia esculenta (L.) flour in comparison with a cereal, tuber and legume flour. Journal of Food Science and Technology, 50(1), 94-100. https:// doi.org/10.1007/s13197-010-0227-6

Kaushal, P., Kumar, V. and Sharma, H.K. (2012). Comparative study of physicochemical, functional, anti-nutritional and pasting properties of taro (Colocasia esculenta), rice (Oryza sativa) flour, pigeon pea (Cajanus cajan) flour and their blends. LWT - Food Science and Technology, 48(1), 59-68. https://doi.org/10.1016/j.lwt.2012.02.028

Kaushal, P., Kumar, V. and Sharma, H.K. (2015) Utilization of taro (Colocasia esculenta): a review. Journal of Food Science and Technology, 52(1), 2740. https://doi.org/10.1007/s13197-013-0933-y

Kayitesi, E., De Kock, H.L., Minnaar, A. and Duodu, K.G. (2012). Nutritional quality and antioxidant activity of marama-sorghum composite flours and porridges. Food Chemistry, 131(3), 837-842. https:// doi.org/10.1016/j.foodchem.2011.09.055

Khetarpaul, N. and Goyal, R. (2007). Effect of supplementation of soy, sorghum, maize and rice on the quality of cooked noodles. Ecology of Food and Nutrition, 46(1), 61-76. https:// doi.org/10.1080/03670240601100600

Maache-Rezzoug, Z., Bouvier, J.M., Allaf, K. and Patras, C. (1998). Effect of principal ingredients on rheological behaviour of biscuit dough and on quality of biscuits. Journal of Food Engineering, 35 (1), 23-42. https://doi.org/10.1016/S0260-8774(98) 00017-X

Mavengahana, S., Mclachlan, M. and De Clercq, W. (2013). The role of wild vegetables species in household food security in maize based subsistence cropping systems. Food Security, 5, 227-233. https://doi.org/10.1007/s12571-013-0243-2

Mbofung, C., Aboubakar, M.F., Njintang, Y.N., Bouba, A. and Balaam, F.F. (2006). Physicochemical and functional properties of six varieties of taro (Colocasia esculenta (L.) Schott). Journal of Food Technology, 4, 135-142.

McEwan, R., Madivha, R.P., Djarova, T., Oyedeji, O.A. and Opoku, A.R. (2010). Alpha-amylase inhibitor of 
amadumbe (Colocasia esculenta): Isolation, purification and selectivity toward $\alpha$-amylases from various sources. African Journal of Biochemistry Research, 4(9), 220-224.

Mergedus, A., Kristl, J., Ivancic, A., Sober, A., Sustar, V., Krizan, T. and Lebot, V. (2015). Variation of mineral composition in different parts of taro (Colocasia esculenta) corms. Food Chemistry, 170, 37-46.

j.foodchem.2014.08.025

Mishra, N. and Chandra, R. (2012). Development of functional biscuit from soy flour and rice bran. International Journal of Agricultural and Food Science, 2(1), 14-20.

Naidoo, K., Amonsou, E.O. and Oyeyinka, S.A. (2015). In vitro digestibility and some physicochemical properties of starch from wild and cultivated amadumbe corms. Carbohydrate Polymers, 125, 915. https://doi.org/10.1016/j.carbpol.2015.02.066

Njintang, N.Y., Boudjeko, T., Tatsadjieu, L.N., Nguema, O.E., Scher, J. and Mbofung, C.M.F. (2014). Compositional, spectroscopic and rheological analyses of mucilage isolated from taro (Colocasia esculenta L. Schott) corms. Journal of Food Science and Technology, 51(5), 900-907. https:// doi.org/10.1007/s13197-011-0580-0

Obadina, A.O., Ishola, I.O., Adekoya, I.O., Soares, A.G., Pier de Carvalho, C.W. and Barboza, H.T. (2016). Nutritional and physico-chemical properties of flour from native and roasted whole grain pearl millet (Pennisetum glaucum (L.) R. Br). Journal of Cereal Science, 70, 247-252. https://doi.org/10.1016/ j.jcs.2016.06.005

Okpala, L.C. and Chinyelu, V.A. (2011). Physicochemical, nutritional and organoleptic evaluation of cookies from pigeon pea (Cajanus cajan) and cocoyam (Xanthosoma sp) flour blends. African Journal of Food, Agriculture, Nutrition and Development, 11(6), 5431-5443.

Omoba, O.S. and Omogbemile, A. (2013). Physicochemical properties of sorghum biscuits enriched with defatted soy flour. British Journal of Applied Science and Technology, 3(4), 1246-1256. https:// doi.org/10.9734/BJAST/2014/4191

Osborne, D.R. and Voogt, P. (1978). Calculation of calorific value. In: The analysis of nutrients in foods., p 239. London: London Academic Press.

Patel, A.S., Kar, A., Pradhan, R.C., Mohapatra, D. and Nayak, B. (2019). Effect of baking temperatures on the proximate composition, amino acids and protein quality of de-oiled bottle gourd (Lagenaria siceraria) seed cake fortified biscuit. $L W T, 106,247$
-253. https://doi.org/10.1016/j.lwt.2019.02.026

Perring, L. and Tschopp, A. (2019). Determination of ash content of milk-based powders by energy dispersive X-ray fluorescence. Microchemical Journal, 145, 162-167. https://doi.org/10.1016/ j.microc.2018.10.025

Rathi, A., Kawatra, A., Sehgal, S. and Housewright, B. (2004). Influence of depigmentation of pearl millet (Pennisetum glaucum L.) on sensory attributes, nutrient composition and in vitro digestibility of biscuits. LWT - Food Science and Technology, 37(2), 187-192. https://doi.org/10.1016/j.lwt.2003.07.003

Serrem, C.A., De Kock, H.L. and Taylor, J.R.N. (2011). Nutritional quality, sensory quality and consumer acceptability of sorghum and bread wheat biscuits fortified with defatted soy flour. International Journal of Food Science and Technology, 46(1), 74 83.

https://doi.org/10.1111/j.13652621.2010.02451.x

Shaheen, N., Islam, S., Munmun, S., Mohiduzzaman, M. and Longvah, T. (2016). Amino acid profiles and digestible amino acid score of proteins from the prioritized key foods in Bangladesh. Food Chemistry, 213, 83-89. https://doi.org/10.1016/ j.foodchem.2016.06.057

Simsek, S. and El, S.N. (2012). Production of resistant starch from taro (Colocasia esculenta (L.) Schott) corm and determination of its effects on health by in vitro methods. Carbohydrate Polymers, 90(3), 12041209. https://doi.org/10.1016/j.carbpol.2012.06.039

Siwela, M. and Amonsou, E.O. (2016). Composition of proteins extracted from two species of leguminous Bauhinia grains. Cereal Chemistry, 93(6), 557-561. https://doi.org/10.1094/CCHEM-04-16-0107-R

Soudy, I.D., De Oliveira, L.A., Nzouzi, N.L., Mamadou, G., Arada, I.A., Atteib, O.D., Idriss, A.O., Eto, B. and Grancher, D. (2014). Comparison of the effectiveness of different traditional soaking processes on the in-vitro digestibility of taro (Colocasia esculenta L. Schott) flour. Journal of Food and Nutrition Sciences, 5, 258-263. https:// doi.org/10.4236/fns.2014.53032

Sozer, N., Cicerelli, L., Heinio, R.L. and Poutanen, K. (2014). Effect of wheat bran addition on in vitro starch digestibility, physico-mechanical and sensory properties of biscuits. Journal of Cereal Science, 60 (1), 105-113. https://doi.org/10.1016/ j.jcs.2014.01.022

Unger, N. and Holzgrabe, U. (2018). Stability and assessment of amino acids in parenteral nutrition solutions. Journal of Pharmaceutical and Biomedical Analysis, 147(5), 125-139. https:// 
doi.org/10.1016/j.jpba.2017.07.064

Vilakati, N., Macintyre U., Oelofse, A. and Taylor, J.R.N. (2015). Influence of micronization (infrared treatment) on the protein and the functional quality of ready-to-eat sorghum-cowpea African porridge for young child-feeding. Journal of Food Science and Technology, 63(2), 1191-1198. https:// doi.org/10.1016/j.lwt.2015.04.017

WHO/FAO/UNU. (2007). Protein and amino acid requirements in human nutrition; Report of a joint WHO/FAO/UNU Expert Consultation, WHO Tech Rep Ser no. 935. Geneva: WHO. Retrieved on August 17, 2019 from WHO Website: https:// www.who.int/nutrition/publications/ nutrientrequirements/WHO TRS 935/en/

Yadav, R.B., Yadav, B.S. and Dhull, N. (2012). Effect of incorporation of plantain and chickpea flours on the quality characteristics of biscuits. Journal of Food Science Technology, 49(2), 207-213. https:// doi.org/10.1007/s13197-011-0271-x

Youssef, M.H.K.E. (2015). Assessment of gross chemical composition, mineral composition, vitamin composition and amino acids composition of wheat biscuits and wheat germ fortified biscuits. Food and Nutrition Sciences, 6, 845-853. https:// doi.org/10.4236/fns.2015.610088 